DOI https://doi.org/10.30525/978-9934-26-110-7-70

\title{
ТИПОЛОГІЧНІ ОЗНАКИ ТУРИСТИЧНОГО ДИСКУРСУ Як ІНСТИТУЦЙНОГО
}

\author{
Іщук А. A. \\ кандидат філософських наук, дочент, \\ дочент кафедри англійської філології \\ Національний педагогічний університет імені М. П. Драгоманова \\ м. Київ, Україна
}

В умовах глобалізації світових процесів у першу чергу розвиваються ті галузі, які відповідають вимогам нового мобільного й динамічного світу i, в той же час, сприяють його формуванню. Однією з таких галузей $\epsilon$ туристична, яка сьогодні розвивається стрімкими темпами і впливає на багато інших сфер людської діяльності. У зв'язку з різноманіттям аспектів, що стосуються цієї галузі, а також міжкультурним характером спілкування, особливий інтерес викликає аналіз комунікації в рамках туристичної сфери.

В останні роки в лінгвістиці активно досліджуються різні типи дискурсів, які відрізняються не лише сферою використання, а й комунікативною метою, прагматичним ефектом. Довгий час туристичний дискурс практично вивчався як соціальний простір організації реклами. Однак існує необхідність більш глибокого, комплексного аналізу мови сфери туризму як мови спеціального призначення на функціональному, комунікативному, прагматичному рівнях.

Н. Миронова так трактує поняття дискурсу: «...це цілісно-оформлена одиниця інформації, що характеризується зв'язністю, обумовлена лінгвістичними та екстралінгвістичними параметрами i являє собою сукупність текстів, що мають схожі теми, принципи побудови та однакові прагматичні параметри» [4, с. 25]. Завдяки такій двозначності, дискурс можна вивчати і як процес, що розгортається у часі, i як структурний об'єкт.

Різними аспектами туристичного та рекламного дискурсу займалися О. Алікіна та С. Мішланова, І. Величко, Л. Виноградова, Л. Гончарова, О. Мішина, О. Мошняга, О. Протченко, Л. Семенюк, О. Скібіцька, Н. Філатова, І. Шукало та інші. У європейській лінгвістиці панує підхід до вивчення мови туризму саме як спеціалізованого, предметно або професійно орієнтованого дискурсу, мови спеціального призначення. Започаткував даний підхід професор Грехем Данн, чия праця «The 
Language of Tourism» [6] стала фундаментальним дослідженням в галузі вивчення туристичного дискурсу. У лінгвістиці поширений соціолінгвістичний підхід до трактування дискурсу, запропонований російським мовознавцем В. Карасиком, у відповідності з яким дискурс можна розділити за адресатним критерієм на персональний (буттєвий) та інституційний (офіційний). «У першому випадку мовець виступає як особистість у всьому багатстві свого внутрішнього світу, у другому випадку - як представник певного соціального інституту» [2, с. 6]. У персональному дискурсі виділяють повсякденний (обслуговує домашні справи тощо, тематично обмежений, збіднений за своїми лінгвальними засобами) та суто буттєвий (слугує художньо-філософському обміну суттєвими смислами у ході пізнання світу). У свою чергу, інституційний (статусно-орієнтований) дискурс - комунікативні практики, що мають місце в суспільних інститутах (політиці, релігії, медицині, науці тощо), які є певним набором доцільно зорієнтованих стандартів поведінки у певних ситуаціях. «нституційний дискурс $є$ спеціалізований клішований різновид спілкування між людьми, які можуть не знати один одного, але повинні спілкуватися відповідно до норм даного соціуму» [3, с. 45-46].

Правомірність виділення туристичного дискурсу в якості особливого виду інституційного дискурсу підтверджується наявністю інститутів (туроператори, міжнародні туристичні організації, міністерства туризму), особливої тематичної спрямованості (подорожі та відпочинок), орієнтації на строго певного адресата (туриста), унікальності мети (поінформувати адресата про туристичний продукт і таким чином стимулювати просування цього продукту), вираження специфічним набором мовних засобів. Як самостійний вид дискурсу туристичний дискурс виділяють також на підставі особливої туристичної етики (Етичний кодекс туризму), спеціальним позначенням певних видів спілкування учасників туристичної комунікації (Міжнародний конгрес 3 туризму), а також наявністю добре розробленої і обширної туристичної термінології.

Говорячи про дискурс, у дослідників виникає потреба у використанні текстів, оскільки спілкування відбувається при посередництві тексту, будь-який дискурс породжує текст. Текст вербалізує поняття, думки, ідеї, що функціонують в межах комунікативної сфери й обслуговує потреби індивідів. Тому досліджуючи комунікативні аспекти туристичного дискурсу доцільно зосередитися на його функціональних характеристиках, жанрово-стилістичних особливостях тощо.

Темою такого дискурсу переважно $\epsilon$ організація туристичних подорожей, прагматична спрямованість текстів зводиться до створення 
привабливого образу тієї або іншої туристичної програми. Туристичний дискурс зазвичай містить текстові компоненти, що мають певні екстралінгвістичні параметри і функціонально пов'язані між собою. Тому дослідження туристичного дискурсу в подальшому неможливе без аналізу текстів, які виступають його результатом, а також функціональних характеристик цього типу дискурсу.

Безпосередній розгляд оформлення туристичного дискурсу можна проводити за схемою, яка включає три рівні аналізу: візуальний (формат, дизайн); структурно-текстовий (характеристика гіпертексту); мовний (лексичні, морфологічні та синтаксичні засоби) [5, с. 120]. Вибір саме цих трьох рівнів аналізу при розгляді різноманітного туристичного матеріалу обумовлений значимістю візуального та структурно-текстового факторів при розгляді мовного оформлення сучасних текстів, наприклад текстів комп’ютерно-опосередкованої комунікації.

Здебільшого туристичний дискурс розглядається як особливий підвид рекламного, оскільки туристична інформація, виражена в тексті, переважно націлена на позиціонування і просування туристичних послуг за допомогою стратегій аргументування. За своєю прагматичною спрямованістю i високою інформаційною насиченістю туристичний дискурс дійсно близький до рекламного. Проте туристичний дискурс має свої особливості, що відрізняють його від рекламного, і визначаються як специфікою самої реклами, так і особливостями сфери туризму та їі продукту: туристичні послуги на відміну від традиційних товарів не мають матеріально вираженої форми. До відмінних рис туристичної реклами належать: 1) неособистісний характер (опосередкованість через рекламоносіі); 2) одностороння спрямованість (від рекламодавця до адресата); 3) невизначеність з точки зору вимірювання ефекту (зважаючи на імовірнісний, невизначений характер придбання туристичного продукту); 4) суспільний характер (у зв'язку з цим велика відповідальність за рекламну інформацію); 5) інформаційна насиченість (забезпечується завдяки інформаційній та комунікативній функціям реклами); 6) помітність i здатність до переконання (припускає використання відео- та фотоматеріалів, зображень, кольорової продукції) [1, с. 36-37].

Тому можемо визначити туристичний дискурс як особливий масовоінформаційний і статусно-орієнтований інституційний дискурс, який $є$ складно організованим, гібридним, поєднує в собі риси рекламного, науково-популярного, дидактичного і полікодового дискурсу, а також використовує вербальні i невербальні елементи. Специфіка даного дискурсу полягає у галузі його застосування - у сфері туризму. 


\title{
Література:
}

1. Дурович А. П. Реклама в туризме: учебное пособие. 4-е изд., стер. Минск: Новое знание, 2008. 254 с.

2. Карасик В. И. О типах дискурса. Языковая личность: институцииональный и персональный дискурс / В. И. Карасик. Волгоград, 2000. C. 5-20.

3. Карасик В. И. Этнокультурные типы институционального дискурса // Этнокультурная специфика речевой деятельности: Сб. обзоров. М.: ИНИОН РАН, 2000. С. 37-64.

4. Миронова Н. Н. Структура оценочного дискурса: дис. ... д-ра филол. наук: 10.02 .04 и 10.02.19. Москва, 1998. 378 с.

5. Щипицина Л. Ю. К вопросу о комплексной характеристике сетевых СМИ. Журналистика и медиаобразование: сб. трудов III Междун. науч.-практ. конф. (Белгород, 25-27 сентября 2008 г.): в 2 т. Т. 1. / под ред. А. П. Короченского. Белгород: БелГУ, 2008. С. 118-122.

6. Dann G. The Language of Tourism. A Sociolinguistic Perspective. Wallingford: CAB International, 1996. 298 p.

DOI https://doi.org/10.30525/978-9934-26-110-7-71

\section{ВИКОРИСТАННЯ ФЕМІНІТИВІВ ЗА ФАХОМ АБО РОДОМ ЗАНЯТЬ В УКРАЇНСЬКИХ МЕДІАТЕКСТАХ}

\author{
Крапива Ю. В. \\ кандидатка філологічних наук, доцентка, \\ дочентка кафедри загального та прикладного мовознавства \\ Харківський нащіональний університет імені В. Н. Каразіна

\section{Медведь О. В.} \\ кандидатка філологічних наук, дочентка, \\ доцентка кафедри документознавства та украӥнської мови \\ Національний аерокосмічний університет \\ імені М. С. Жуковського «Харківський авіачійний інститут» \\ м. Харків, Украӥна
}

У сучасному світі спостерігаємо зміну соціального статусу жінки, яка намагається реалізувати ті суспільні функції, які їй цікаві. Ідеться про збільшення громадської та професійної активності жінок, що не обмежуються тільки роллю домогосподарки й поступово відвойовують 